i APR, 51963

Photostat Price $\$$

Microfilm Price $\$$

Available from the

Office of Technical Services

Department of Commerce

Washington 25, D. C.
MASTER

1 18430

\title{
ON DISPERSION STRENGTHENING OF ZIRCONIUM
}

D. Weinstein

F. C. Holtz

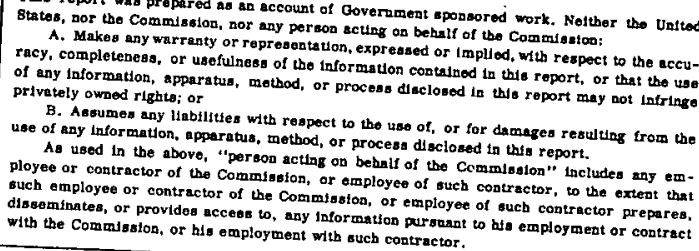

*D. Weinstein, Junior Member AIME, and F. C. Holtz are Research Metallurgist and Senior Metallurgist, respectively, Metals and Ceramics Research Division, Armour Research Foundation, Chicago, Illinois. This work was supported by Atomics International and the U. S. Atomic Energy Commission under Contract No. AT (11-1)-578, Project Agreement No. 21.

This document is PUBLICL ' RELEASABLE 


\section{DISCLAIMER}

This report was prepared as an account of work sponsored by an agency of the United States Government. Neither the United States Government nor any agency Thereof, nor any of their employees, makes any warranty, express or implied, or assumes any legal liability or responsibility for the accuracy, completeness, or usefulness of any information, apparatus, product, or process disclosed, or represents that its use would not infringe privately owned rights. Reference herein to any specific commercial product, process, or service by trade name, trademark, manufacturer, or otherwise does not necessarily constitute or imply its endorsement, recommendation, or favoring by the United States Government or any agency thereof. The views and opinions of authors expressed herein do not necessarily state or reflect those of the United States Government or any agency thereof. 


\section{DISCLAIMER}

Portions of this document may be illegible in electronic image products. Images are produced from the best available original document. 
As a possible method of improving the elevated temperature strength properties of zirconium, an investigation was initiated on the feasibility of producing a dispersion-strengthened material. Because of the high reactivity of zirconium, its high solubility for oxygen, and the stability of the zirconium-oxygen solid solution, the major problem in such a development is choice of a suitable dispersant. That is, the dispersant must not react with the matrix at temperatures required for fabrication or at temperatures encountered during service. Thus, in the present investigation we were concerned primarily with the stability of various dispersants in the zirconium matrix.

The procedure employed in this study consisted essentially of blending powders of zirconium and a dispersant, followed by cold compaction and extrusion. The best available source of -325 mesh zirconium powder contained between 1500 and $3500 \mathrm{ppm} \mathrm{O}_{2}$; to this material, powders of zirconium carbide $(5 \mu \max$.$) ,$ vanadium carbide $(5 \mu \max )$ ), alumina $(0.03 \mu$ average), lanthana $(0.8-2 \mu)$, ceria $(0.8-2 \mu)$, yttria $(0.8-2 \mu)$, calcia $(44 \mu \max )$, or thoria $(0.6-0.8 \mu)$ were added in amounts of 7 vol \% and compacted at 65 tsi. A cylindrical "green" compact having a density between 70 and 80 per cent of theoretical and dimensions of 1 inch diameter by $11 / 4$ inch high was thus produced. After canning in copper, these billets could be extruded (5:1) on a 54-ton capacity, slow traverse hydraulic press with 
the billet temperature at $1550^{\circ} \mathrm{F}$ and the extrusion die at $900^{\circ} \mathrm{F}$. However, lack of densification of some of the extruded billets necessitated ratios of at least 23:1. For this high area reduction, the small size, slow press was not capable of extruding dispersed materials; only zirconium powder with no added particles was successfully extruded at high ratios using this press. This observation immediately indicated a pronounced strengthening effect due to the particles. Ultimately, all billets were successfully extruded at $1500^{\circ} \mathrm{F}$ to 0.190 inch diameter, fully dense rods (32:1) using a 200-ton capacity press and a ram speed of 90 ipm.

The microstructure of as-extruded $\mathrm{Zr}-7$ vol \% $\mathrm{La}_{2} \mathrm{O}_{3}$ and $\mathrm{Zr}-7$ vol $\% \mathrm{Y}_{2} \mathrm{O}_{3}$ are shown in Figures 1(a) and $1(c)$, respectively. These structures are similar to all the as-extruded materials and consist of an elongated, single-phase zirconium matrix dispersed with oxide or carbide particles.

Very little porosity is observed, and the inter face between matrix and particles appears satisfactory. The size and distribution of particles, however, are not ideally of the type desired for strengthening by a dispersion of particles. Since the primary study was of particle stability with respect to zirconium, no attempt was made to overcome agglomeration during powder blending and fabrication. Some areas exhibit 


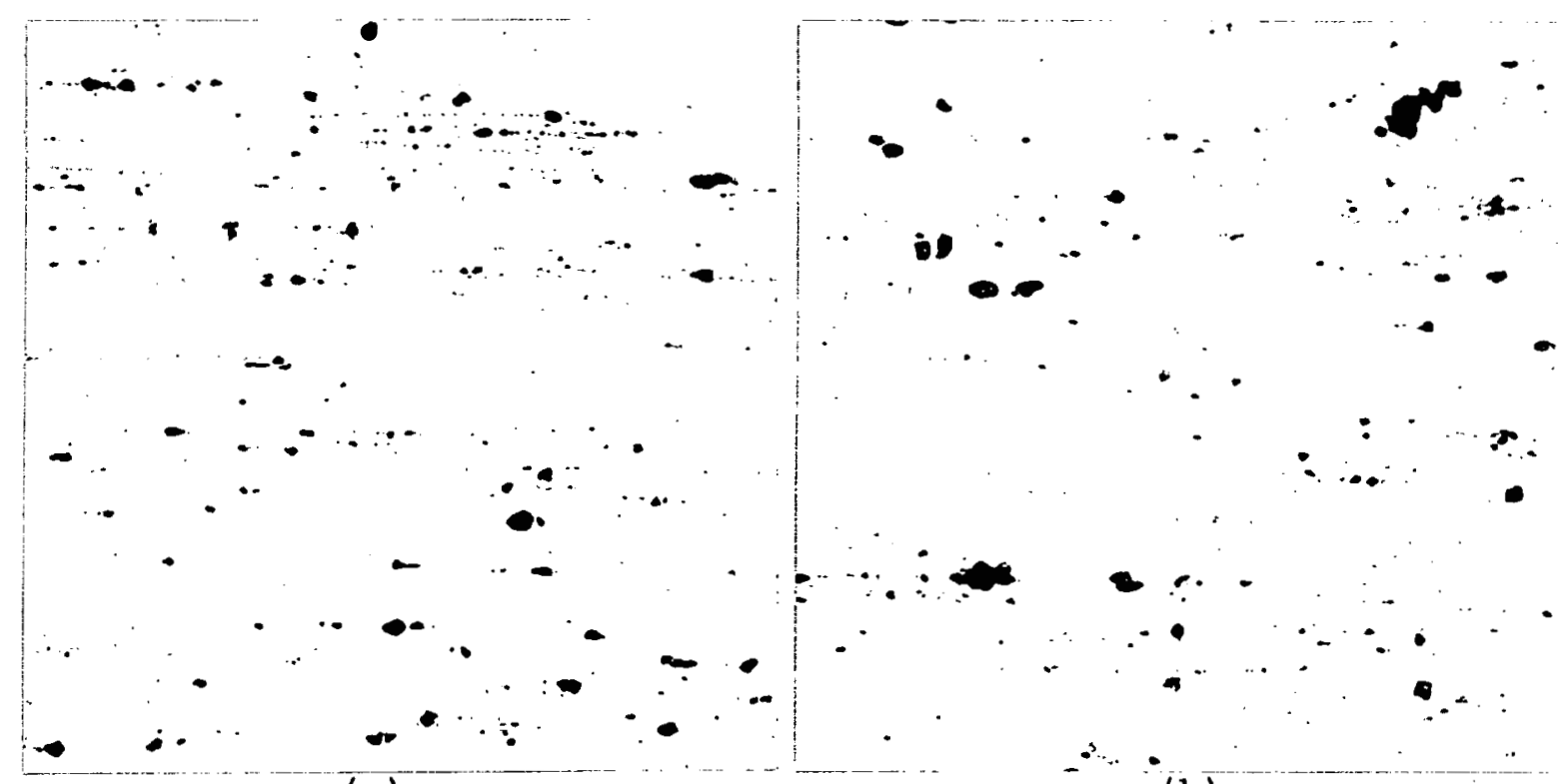

(a)

(b)

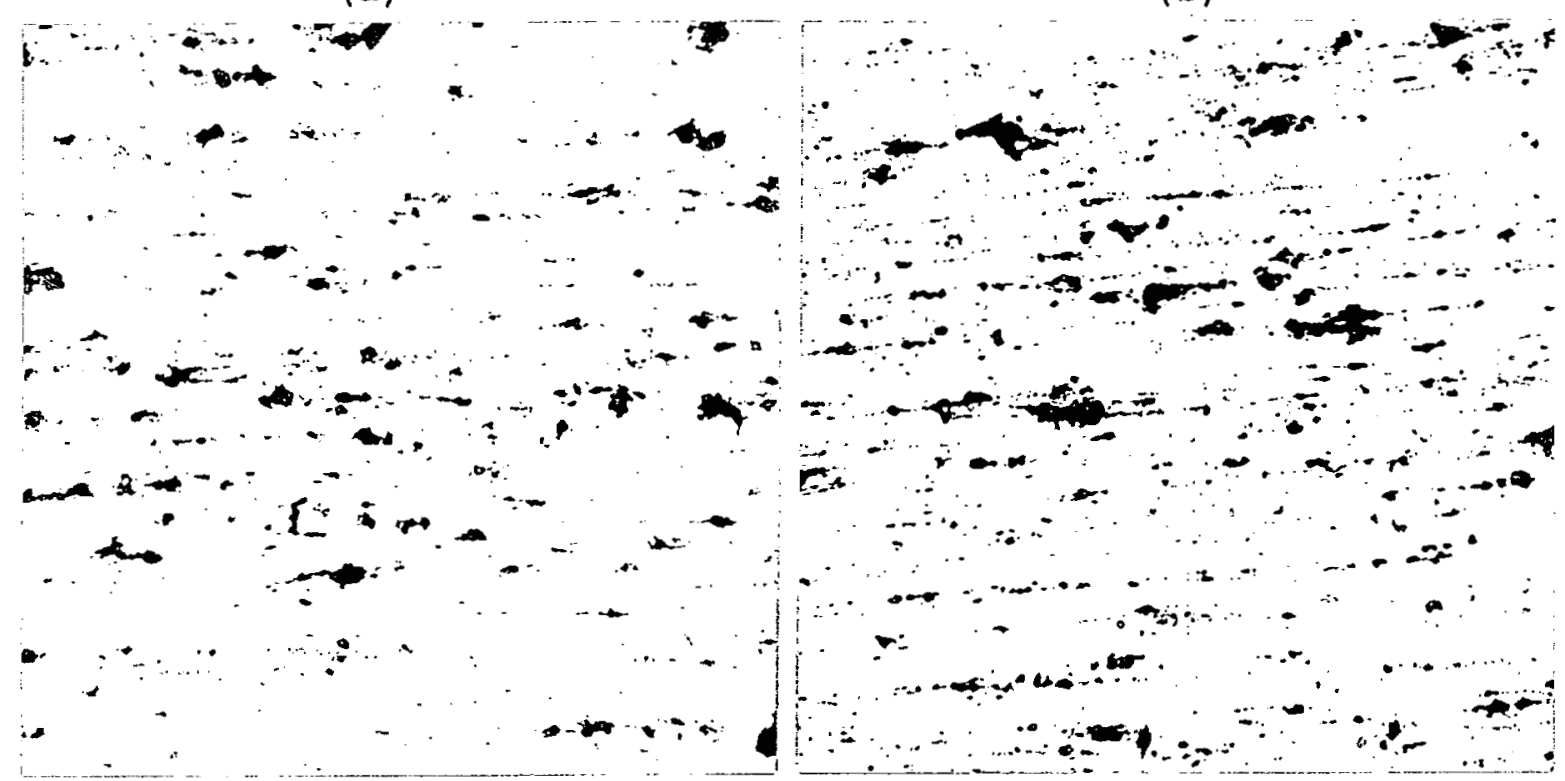

(c)

(d)

Fig. 1 - Microstructures of particle-dispersed zirconium, as-extruded and after annealing. Unetched, $\times 500$. (a) $\mathrm{Zr}-7$ vol $\% \mathrm{La}_{2} \mathrm{O}_{3}$ as -extruded; (b) $\mathrm{Zr}-7$ vol $\% \mathrm{La}_{2} \mathrm{O}_{3}$ annealed $1600^{\circ} \mathrm{F}, 10$ days; (c) $\mathrm{Zr}-7$ vol \% $\mathrm{Y}_{2} \mathrm{O}_{3}$ as -extruded; (d) $\mathrm{Zr}-7$ vol $\% \mathrm{Y}_{2} \mathrm{O}_{3}$ annealed $1600^{\circ} \mathrm{F}, 10$ days. These oxide particles remained stable in the zirconium matrix. 
fine, well-distributed particles; undoubtedly, a small proportion is submicroscopic and has the proper size (about $0.01 \mu$ ) and particle spacing $(0.01$ to $1 \mu$ ) for optimum strengthening.

The ambient temperature for service applica tion of these materials is $1200^{\circ} \mathrm{F}$. To test particle stability, specimens of as-extruded materials were annealed in sealed, helium-filled bulbs at $1600^{\circ} \mathrm{F}$ for 10 days. Any dispersants which show stability in zirconium at $1600^{\circ} \mathrm{F}$ would undoubtedly exhibit stability at the lower service temperature. The microstructure of the lanthana and yttria dispersed materials are shown in Figures $1(b)$ and $1(d)$, respectively, afte $r$ annealing at $1600^{\circ} \mathrm{F}$ for 10 days. These dispersants remained stable in the zirconium matrix; there is no indication of particle reduction, agglomeration, rounding, or solution of these oxides in zirconium after the annealing treatments. Essentially, there is no difference in microstructure before or after annealing (except for matrix recrystallization, which is not shown). The specimen containing 7 vol $\% \mathrm{ThO}_{2}$ behaved in a similar manner; however, the other specimens containing oxides and the carbide-dispersed materials showed evidence of particle instability. Such behavior was manifested by. change in the matrix area surrounding a particle, grain boundary penetration much like that observed for liquid-phase boundary 
wetting, particle rounding and agglomeration, dissolution of the particles, or hardness increase.

Tensile and stress-rupture specimens having a gage diameter of 0.100 inch were machined from the as-extruded rods and evaluated at $1200^{\circ} \mathrm{F}$. A summary of data on those materials considered promising from the standpoint of particle stability is presented in Table $I$. The value of tensile strength for undispersed zirconium is slightly higher than data reported elsewhere; $(1,2)$ however, the latter data are not in agreement. While the elongated structure of extruded rods might account for the slightly high tensile strength at $1200^{\circ} \mathrm{F}$, the high oxygen content (about 3000 ppm) probably does not cause strengthening at this temperature. According to Rubenstein, (3) oxygen has only a very small effect on hardness of zirconium at $1100^{\circ} \mathrm{F}$ ard therefore probably would not influence tensile and stressrupture properties at $1200^{\circ} \mathrm{F}$. The tensile strength and the 100-hour stress-rupture strength of dispersed materials are higher than the strength of undispersed zirconium, and this behavior is undoubtedly due to the particle additions. It must be emphasized that neither the ideal particle size nor optimum interparticle spacing exists in the microstructure except for perhaps a very small percentage of particles. No attempt was made to optimize particle size or amount 
TABLE I. Mechanical Properties of Experimental Zirconium Alloys at $1200^{\circ} \mathrm{F}$.

\begin{tabular}{ccccc}
\hline $\begin{array}{c}\text { Ultimate } \\
\text { Composition, } \\
\text { vol \% }\end{array}$ & $\begin{array}{c}\text { Strength, } \\
\text { psi }\end{array}$ & $\begin{array}{c}\text { Yield } \\
\text { Stress, } \\
\text { psi }\end{array}$ & $\begin{array}{c}\text { Elongation, } \\
\%\end{array}$ & $\begin{array}{c}100 \text {-hour R upture } \\
\text { Strength, psi }\end{array}$ \\
\hline Undispersed $\mathrm{Zr}$ & 8,600 & 8,400 & 37.5 & 2,000 \\
$\mathrm{Zr}+7 \mathrm{La}_{2} \mathrm{O}_{3}$ & 14,000 & 13,000 & 15 & $--^{*}$ \\
$\mathrm{Zr}+7 \mathrm{Y}_{2} \mathrm{O}_{3}$ & 14,600 & 14,600 & 36 & 2,800 \\
$\mathrm{Zr}+7 \mathrm{ThO}_{2}$ & 16,200 & 16,200 & 23 & 3,600 \\
\hline
\end{tabular}

* A threaded specimen was required for stress-rupture tests; it was not possible to machine threads on the lanthana-dispersed material. 
of particles added. With the total amount of particles existing as an optimum or "critical dispersion," strengths of much higher magnitude would be anticipated. Since some particle strengthening was noted and since particle stability was demonstrated to a certain extent, it appears that dispersion strengthening of zirconium is feasible.

1. R. J. Van Thyne and D. J. McPherson: Trans. ASM, 1956, vol. 48, p. 795.

2. R. K. Wagner and $H$. E. Kline: Trans. ASM, 1960, vol. 52 , p. 713 .

3. L. S Rubenstein: "Zirconium Highlights," WAPD-ZH-17, May 1959. 